\title{
Erkek Hastada Ektopik Meme Olgusu
}

\section{Ectopic Breast in a Male Patient: A Case Report}

\author{
Bülent Koca, Serdar Şenol, Hamza Çınar, Savaş Yürüker \\ Ondokuz Mayıs Üniversitesi Tıp Fakültesi, Genel Cerrahi Anabilim Dalı, Samsun, Türkiye
}

\section{Özet}

Kliniğimizde tanı koyduğumuz ve tedavi ettiğimiz 25 yaşındaki erkek hastamız eşliğinde ektopik meme, meme başı ve areola kompleksinin özelliklerini, tanı ve tedavi yöntemleriyle birlikte klinik önemini tartışmayı amaçladık. (Haseki Tıp Bülteni 2013; 51: 26-7)

Anahtar Kelimeler: Meme, erkek, ektopik meme

\begin{abstract}
In this study, we describe a case report of a 25-year-old male who was diagnosed with ectopic breast tissue and was treated in our clinic. Subsequently, we to discuss clinical presentation, diagnosis, treatment, and clinical significance of ectopic breast and nippleareola complex. (The Medical Bulletin of Haseki 2013; 51: 26-7)
\end{abstract}

Key Words: Breast, male, ectopic breast

\section{Giriş}

Ektopik meme nadir görülen bir durumdur ve genellikle ektopik dokuda meme dokusu, areola ve meme başı bir arada bulunmaz. Ektopik meme dokusu kadınlarda \%1-6 oranında görülürken erkek cinsiyet için literatürde bir oran bildirilmemiştir (1). Kliniğimizde tanı koyduğumuz erkek hastamız eşliğinde ektopik meme, meme başı ve areola kompleksinin özelliklerini ve klinik önemini tartışmayı amaçladık. Hastamızın erkek olmasının ve ektopik dokuda meme, meme başı ve areolanın bütün halinde bulunmasının bu olgu sunumunu daha ilginç hale getirdiğini düşünmekteyiz.

\section{Olgu Sunumu}

Yirmi beş yaşında erkek hasta kendisini kozmetik olarak rahatsız eden, sol meme altında kitle nedeniyle kliniğimize başvurdu. Muayenede saat yedi yönünde sol meme başına yaklaşı $10 \mathrm{~cm}$ mesafede $1-2 \mathrm{~cm}$ çapında, etrafında kıllanması olan meme başı-areola kompleksi olduğu görüldü ve areola altında bir miktar meme dokusu palpe edilirken kitle palpe edilmedi (Resim 1). Bilateral meme ve aksilla muayenesi normaldi. Yüzeyel ultrasonda ektopik meme başı-areola kompleksi altında kitle saptanmadı. Malignite şüphesi olmadığından meme başı-areola kompleksi meme dokusu olduğu düşünülen cilt altı dokularla birlikte lokal anestezi ile cerrahi olarak eksize edildi. Eksizyon lojuna dren konulmadı. Hasta postoperatif 1. gün herhangi bir komplikasyon olmadan taburcu edildi ve 7. gün kontrol muayenesine geldiğinde dikişleri alındı. Patoloji sonucu meme, meme başı ve areola altında meme dokusu olduğu şeklinde rapor edildi (Resim 2).

\section{Tartışma}

Ektopik meme dokusu \%1-6 oranında görülürken genellikle süt çizgisi üzerinde ortaya çıkar (1). Yüz, vulva, boyun, uyluk, üst ve alt ektremiteler de ektopik meme başı ve ektopik memenin yerleşebileceği alanlardır. Genellikle meme dokusu, areola ve meme başı ektopik dokuda bütün halinde bulunmazlar. Ektopik memede nadiren bu üç yapı bir arada bulunur. Ektopik meme dokusu normal meme dokusu gibi hormonal değişimlerden etkilenerek benzer biçimde proliferatif değişimler göstermektedir (2). Puberte, menarş ve gebelik durumlarında ektopik meme dokusunda da bir takım fizyolojik değişimler olması kaçınılmazdır. Kist, mastit, papillom, fibroadenom, hiperplazi gibi benign patolojilerin yanında kanser gelişimi de görülebilmektedir (3-6). Literatürde primeri belli olamayan aksillada meme kanseri metastazıyla tanı konulan ektopik meme olgusu da mevcuttur (7). Ektopik memede kanser gelişme oranının normal meme dokusundakinden farklı olup olmadığını bildiren bir yayın yoktur. Ektopik meme dokusu pilor stenozu, kalp, kulak, idrar
Yazışma Adresi/Address for Correspondence: Bülent Koca 1Ondokuz Mayıs Üniversitesi Tıp Fakültesi, Genel Cerrahi, Samsun, Türkiye Tel.: +90 3623121919 E-posta: dr.bulentkoca@mynet.com

Geliş Tarihi/Received: 04 Ekim 2012 Kabul Tarihi/Accepted: 17 Kasım 2012
The Medical Bulletin of Haseki Training and Research Hospital, published by Galenos Publishing. All rights reserved. Haseki Tıp Bülteni, Galenos Yayınevi tarafından basılmıştır. Her hakkı saklıdır. 


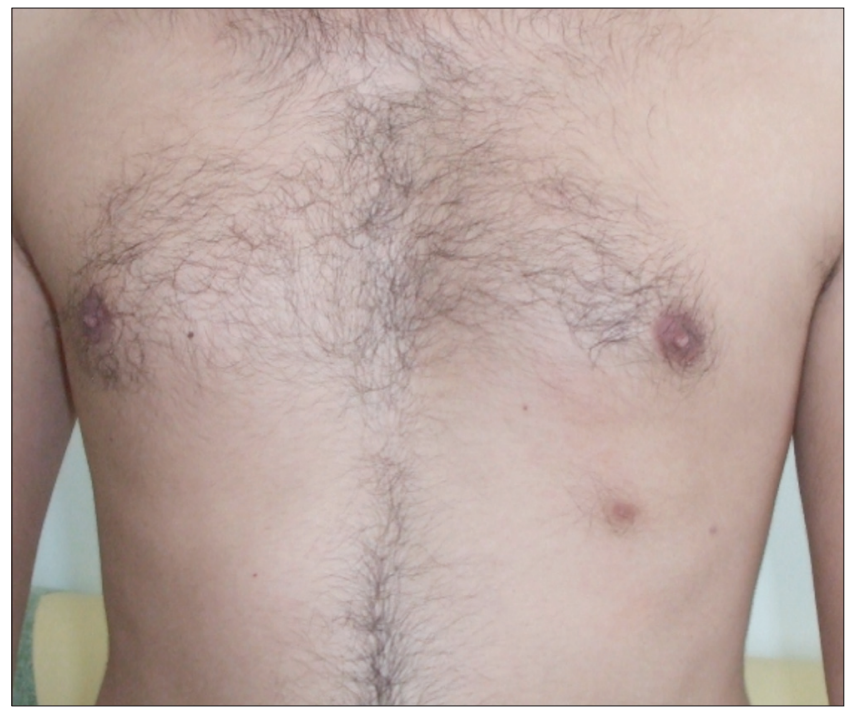

Resim 1. Sol meme areolaya $10 \mathrm{~cm}$ mesafede saat yedi yönünde ektopik meme (meme başı-areola, meme dokusu ve kıllanması ile komplet ektopik meme)

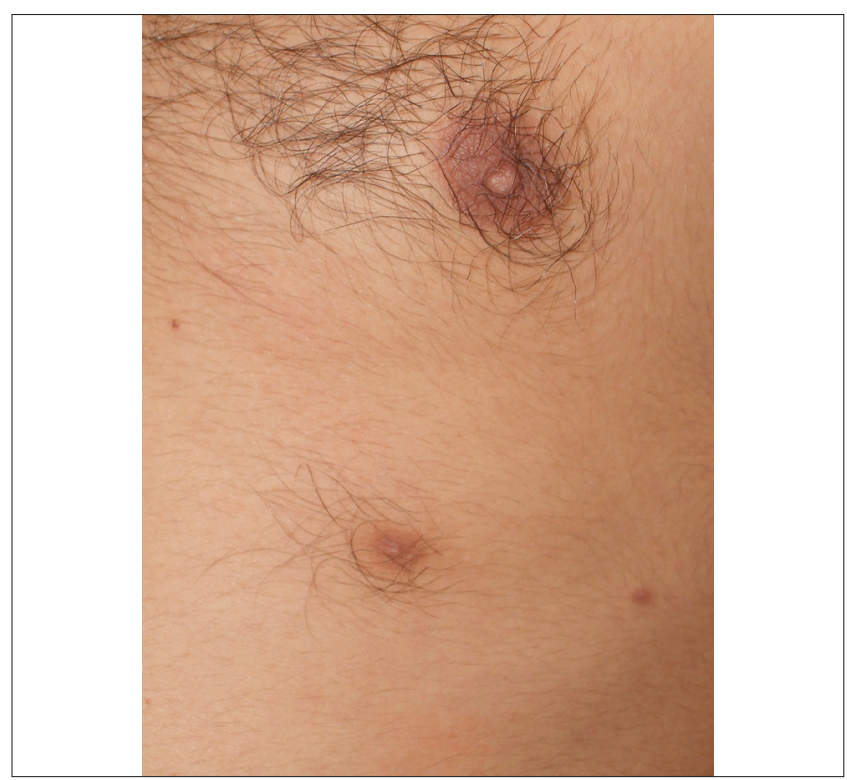

Resim 2. Ektopik memenin yakından görünümü

yolu anomalileri ve böbrek adenokanseri ile birlikte görülebilir (8). Biz de hastamıza üst endoskopi, renal ultrason ve ekokardiyografi tetkikleri yaptırarak var olabilecek anomalileri araştırdık ve herhangi bir anomali olmadığını saptadık.
Mamografi, ultrasonografi ve manyetik rezonans görüntüleme tanıda kullanılabilir (9). Ektopik meme dokusunun kor biyopsisi uygun cerrahi kararı vermekte önemlidir. Özellikle ektopik meme dokusu içinde palpe edilen bir kitle varlığında ve malignite şüphesi var ise kor biyopsisi Malign riski olmayan ektopik meme dokusu tedavisinde bizim olgumuzda yapıldığı gibi lokal eksizyon yeterliyken, malign tanısı olan olgularda komplet eksizyon ve aksiller değerlendirme sonrasında aksiller lenf nodu diseksiyonu yapılmalıdır (10). Malign ektopik meme dokusunda cerrahi sonrası adjuvan kemoterapi, radyoterapi ve reseptör durumu uygun ise hormon tedavisi uygulanmalıdır $(3,11)$.

\section{Sonuç}

Ektopik meme sadece kozmetik bir sorun değildir. Ektopik meme dokusunda benign ve malign tüm meme patolojlerinin bulunabileceği akılda tutulmalı, tanı ve tedavisinde bu özellikleri göz önünde bulundurulmalıdır.

\section{Kaynaklar}

1. Gutermuth J, Audring H, Voit C, Haas N. Primary carcinoma of ectopic axillary breast tissue. J Eur Acad Dermatol Venereol 2006;20:217-21.

2. Cheong JH, Lee BC, Lee KS. Carcinoma of the axillary breast. Yonsei Med J 1999:40:290-3.

3. Goyal S, Puri T, Gupta R, Julka PK, Rath GK. Accessory breast tissue in axilla masquerading as breast cancer recurrence. J Cancer Res Ther 2008;4:95-6.

4. Shin SJ, Sheikh FS, Allenby PA, Rosen PP. Invasive secretory (juvenile) carcinoma arising in ectopic breast tissue of the axilla. Arch Pathol Lab Med 2001;125:1372-4.

5. Gendler LS, Joseph KA. Images in clinical medicine. Breast cancer of an accessory nipple. N Engl J Med 2005;27:1835.

6. Seifert F, Rudelius M, Ring J, Gutermuth J, Andres C. Bilateral axillary ectopic breast tissue. Lancet 2012;1:380-5.

7 Capobianco G, Spaliviero B, Dessole S, et al. Lymph node axillary metastasis from occult contralateral infi Itrating lobular carcinoma arising in accessory breast: MRI diagnosis. Breast J 2007;13:305-7.

8. Goedert JJ, McKeen EA, Fraumeni JF Jr. Polymastia and renal adenocarcinoma. Ann Intern Med 1981;95:182-4.

9. Bayar S, Çakmak A, Akyol C, Demirci S. Aksesuar memede gelişen fibroadenom. Meme Sağlığı Dergisi 2009;2:112-3.

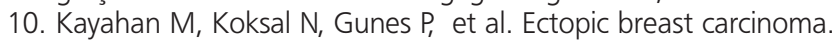
J Coll Physicians Surg Pak 2009;19:734-6.

11. Lopes G, DeCesare T, Ghurani G, et al. Primary ectopic breast cancer presenting as a vulvar mass. Clin Breast Cancer 2006;7:278-9. 